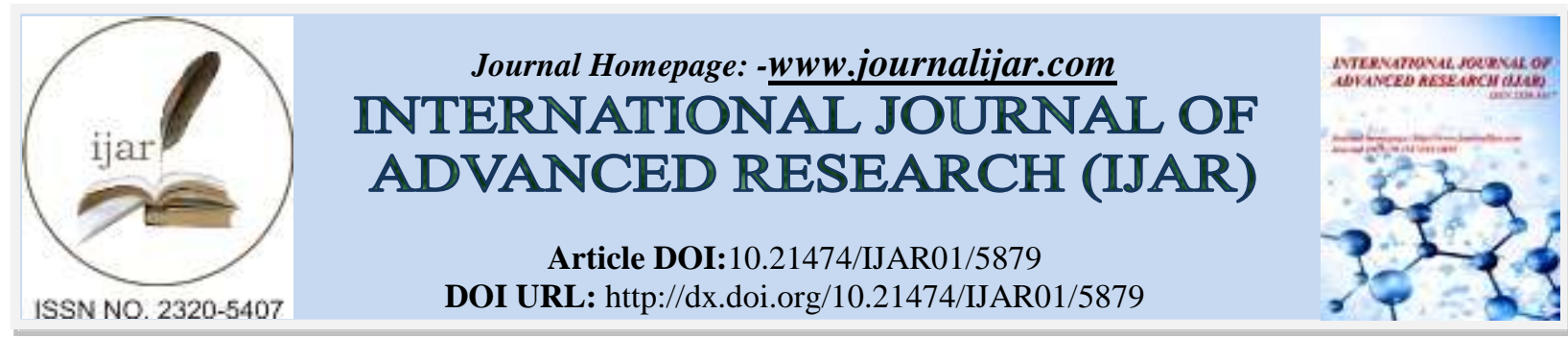

RESEARCH ARTICLE

\title{
POLICIES AND MEASURES FOR ECONOMIC EFFICIENCY, ENERGY SECURITY AND ENVIRONMENT PROTECTION IN INDIA.
}

Prof. Dr. M. Venkaiah.

Principal, MNR College of Engineering \& Technology, Hyderabad, T.S., India-502294.

\section{Manuscript Info}

Manuscript History

Received: 16 September 2017

Final Accepted: 18 October 2017

Published: November 2017

Key words:-

Economic Efficiency; Environment

Protection; Energy Security.

\begin{abstract}
India faces formidable challenges in meeting its energy needs and providing economical and adequate energy in environment friendly forms to end users in a sustainable manner. Therefore it needs to sustain $8 \%$ to $10 \%$ economic growths to supply energy for economically deprive people to meet their goals of higher education and environment friendly life style. India would at least, need to grow its primary energy supply by 3 to 4 times of present consumption in order to deliver a sustained growth of $8 \%$ through 2031. Energy challenge is of primary concern to national economic growth as it needs improvised qualitative and quantitative energy supply. In this paper, policies and measures are discussed aiming for Economic Efficiency, Environment Protection and Energy Security (3-E) for India as well as for the planet home.
\end{abstract}

Copy Right, IJAR, 2017,. All rights reserved.

\section{Introduction:-}

Spectrum of vision for economic efficiency, environment protection and energy security (3-E) goals is to reliably supply, conserve and regenerate lifeline energy in a technically efficient, economically viable and environmentally sustainable manner. India pursues all available fuel options and forms of energy, both conventional and non-conventional, as well as new and emerging technologies and energy sources. Coal shall remain major energy source till 2031-32. India will need to take a lead in seeking clean coal technologies such as extraction and in-situ gasification to tap its vast coal reserves using conventional technologies [1]. There is a need of feasibility study for economically viable imports of such energy sources among mutually friendly nations for their complementary exchanges of supply and demand cycles of energy.

Implementation of vision for 3-E goals needs actions as follows:

i Open and free trading market policy for mutually beneficial and strategically important energy substances and products.

ii Pricing and resource allocation under an effective and foresight policy.

iii Subsidies and royalties to people in need to strengthen and sustain biogenetic divinities of nature and species redefining efficiencies for energy recycling in order to strengthen environment friendly life styles.

iv Transparency in energy consumption per capita among nations.

Service based marketing policy in trade free environment is feasibly most efficient and intelligent way to realize steady state conditions for consumptions and regeneration of energy in cosmic energy recycling environment. Tax structure and regulation across energy sub-sectors should enhance this marketing policy by facilitating federative infrastructure to all energy players. Environmental violations should be treated uniformly with imposition of penalty on environmentally destructive practices. An energy market with the foregoing features would minimize market distortions and maximize efficiency gains. An integrated energy policy is needed to ensure recycling and enhancing energy resources for developing economy towards developed nation in form of intelligent and self-sustained way of interdependent living in harmony with flourishing nature.

While the medium to long-term challenges of ensuring competitive energy supplies from other nations are formidable, the immediate problem of power and coal shortages also requires policy actions. The medium to long-term issues are summarized in the following sections. 


\section{Coal Sector:-}

Coal accounts for over $50 \%$ of India's commercial energy consumption and $78 \%$ of domestic coal production is dedicated to power generation (Table 2.1). Since prices were de-controlled, the sector has become profitable primarily as a result of price increases and rising share of open cast production. Present shortage can be addressed by encouraging imports and to create needed infrastructure for longer-term perspective. Imports also put a competitive pressure on domestic coal industry for their better efficiency. At the same time domestic coal production should be encouraged by allotting coal blocks and captive mines to central and state public sector units Coal Mines (Nationalization) Act, 1973 should be amended to facilitate private participation in coal mining for potential entrepreneurships.

Table 2.1:- Demand projection of coal by various industries in million tonnes

\begin{tabular}{|c|c|c|c|c|c|c|c|c|c|c|c|c|}
\hline Source & Sectors/Period & $\begin{array}{l}\text { Base } \\
\text { year }\end{array}$ & $06-07$ & 2010 & $2011-12$ & 2015 & $2016-17$ & $2020-21$ & $2021-22$ & $2024 \cdot 25$ & 2025 & 2030 \\
\hline \multirow{7}{*}{$\begin{array}{l}\text { XPlan working } \\
\text { group }\end{array}$} & Power & & 322 & & 469 & & 617 & & & & & \\
\hline & Captive Power & & 28 & & 32 & & 37 & & & & & \\
\hline & Steel & & 43 & & 40 & & 40 & & & & & \\
\hline & Cement & & 25 & & 24 & & 25 & & & & & \\
\hline & Fertiliser & & 4 & & 5 & & 5 & & & & & \\
\hline & Others & & 51 & & 50 & & 56 & & & & & \\
\hline & Total & 2001.02 & 473 & & 620 & & 780 & & 981 & 1126 & & \\
\hline \multirow{7}{*}{$\begin{array}{l}\text { Coal Vision } \\
2025^{\circ} 7 \% \\
\text { GDP }\end{array}$} & Power & & 322 & & 413 & & 517 & & 635 & 719 & & \\
\hline & Captive Power & & 28 & & 43 & & 60 & & 84 & 102 & & \\
\hline & Fertiliser & & 4 & & & & & & & & & \\
\hline & Steel & & 43 & & 53 & & 67 & & 84 & 97 & & \\
\hline & Cement & & 25 & & 38 & & 58 & & 88 & 113 & & \\
\hline & Others & & 51 & & 64 & & 80 & & 101 & 117 & & \\
\hline & Total & $2006-07$ & 473 & & 611 & & 782 & & 992 & 1147 & & \\
\hline \multirow{7}{*}{$\begin{array}{l}\text { Coal Vision } \\
2025^{\circ} 8 \% \\
\text { GDP }\end{array}$} & Power & & 322 & & 427 & & 553 & & 699 & 804 & & \\
\hline & Captive Power & & 28 & & 44 & & 63 & & 90 & 112 & & \\
\hline & Fertiliser & & 4 & & & & & & & & & \\
\hline & Steel & & 43 & & 54 & & 69 & & 90 & 105 & & \\
\hline & Cement & & 25 & & 39 & & 61 & & 95 & 123 & & \\
\hline & Others & & 51 & & 65 & & 82 & & 106 & 123 & & \\
\hline & Total & $2006-07$ & 473 & & 630 & & 828 & & 1079 & 1267 & & \\
\hline $\begin{array}{l}\text { Hydrocarbon } \\
\text { Vision } 2025\end{array}$ & & 1998.99 & & & & & & 1118 & & 1402 & 1483 & \\
\hline \multirow[t]{2}{*}{$\begin{array}{l}\text { India Vision } \\
2020\end{array}$} & $\begin{array}{l}\text { Best Case } \\
\text { Scenario }\end{array}$ & 1997.98 & & & & & & 538 & & 659 & & \\
\hline & $\begin{array}{l}\text { Business As } \\
\text { Usual }\end{array}$ & (311) & & & & & & 688 & & 971 & & \\
\hline \multirow[t]{3}{*}{ EIA } & High & 2001 & & 408 & & 473 & & 548 & & 611 & 629 & \\
\hline & Low & & & 374 & & 411 & & 447 & & 481 & 490 & \\
\hline & Reference & & & 390 & & 439 & & 493 & & & & \\
\hline IEA & & 2000 & & 484 & & & & 623 & & 713 & & 817 \\
\hline $\begin{array}{l}\text { P\&E Division, } \\
\text { Plg. Comm. }\end{array}$ & & 2001 & 481 & & 612 & & 764 & 920 & 957 & & & $\begin{array}{r}1417 \\
12031-38\end{array}$ \\
\hline
\end{tabular}

\section{Power Sector:-}

Power Sector Reforms must focus on technical and commercial losses of state power utilities[2]. Only financially healthy state power utilities can sustain as State Public Sector Units (SPSUs) and provide the conducive environment to attract private investment in the power sector at internationally competitive tariffs. Existing Accelerated Power Development and Reform Programmed (APDRP) is to be restructured to ensure energy flow auditing and minimizing Aggregate Technical and Commercial (AT\&C) losses Geographical Information System (GIS) of the power distribution network, consumers and separation of feeders for agricultural pumps to enhance energy efficiency.

\section{Reduce Cost of Power:-}

In terms of purchasing power parity, power tariffs in India for industry, commerce \& large households are among the highest in the world. A number of measures are suggested to reduce cost of power [3].

(a) Government should enhance the capital markets for around 20 years to develop market based instruments for power projects.

(b) Standardization of energy flow measuring devices in power distribution networks substantially enhances the energy efficiency. 


\section{Fuel Prices:-}

Relative prices play major role in choice of fuel and energy form. They are thus the most vital aspect of Energy Planners that promotes efficient fuel choices and facilitates appropriate environment friendly substitution. In a competitive set up, prices of different fuels at different places do not differ by more than the cost of transporting fuels. Prices of different fuels should not be set independently of each other. As a general rule, all commercial primary energy sources must be priced at trade parity prices at the point of sale.

Central and State taxes on commercial energy supplies need to be rationalized to yield optimal fuel choices and investment decisions. Relative prices of fuels can be distorted if taxes and subsidies are not equivalent across fuels, in term of effective calorie. Environmental taxes and subsidies, however, are levied to affect choices. Differential taxes can be justified here if they appropriately reflect environmental violations.

\section{Energy Efficiency and Demand Side Management:-}

Economic efficiency offers a powerful and cost-effective tool for achieving energy conservation and conversion efficiency for a sustainable energy future. Improvements in economic efficiency can reduce the need for investment in energy infrastructure, cut fuel costs, increase competitiveness and improve consumer welfare. Environmental benefits can also be achieved by the reduction of greenhouse gas emissions and local air pollution.

Energy Intensity of an economy refers to the energy consumption per unit of GDP. The economic growth and energy demand are linked, however energy intensity is influenced by the stage of the economic development of a particular economy and the standard of living of individuals.

Lowering energy intensity of GDP growth through higher energy efficiency is a key to solve energy challenge and ensuring energy security. India's energy intensity of growth has been falling about half than that of early seventies. Currently India consumes 0.19 kilogram of oil equivalent per dollar of GDP expressed in purchasing power parity terms. This is equal to the energy intensity of the Organization for Economic and Cultural Development (OECD) which is better than 0.21 kilograms of China, 0.22 kilograms of the US and a World average of 0.2. However, there are several countries in Europe and Asia at or below 0.12 with Brazil at 0.14 and Japan at 0.15 . Energy intensity can be brought down significantly around $25 \%$ in India with current commercially available technologies [4]. In many cases the purchase decision is based on initial cost, but the operating cost predominates as compared to the initial capital cost. This has been shown in Table 5.1.

Table 5.1:- Comparison of Initial Cost and Life Cycle Cost

\begin{tabular}{|l|l|l|c|c|c|c|}
\hline $\begin{array}{l}\text { SI. } \\
\text { No. }\end{array}$ & Equipment & Rating & $\begin{array}{c}\text { Initial cost } \\
\text { (Rs) }\end{array}$ & $\begin{array}{c}\text { Annual } \\
\text { Electricity Cost } \\
\text { (Rs) }\end{array}$ & $\begin{array}{c}\text { ALCC } \\
\text { (Rs) }\end{array}$ & $\begin{array}{c}\text { Cost of } \\
\text { electricity as } \\
\% \\
\text { of ALCC }\end{array}$ \\
\hline 1. & Motor & $20 \mathrm{hp}$ & 45,000 & 600,000 & $\begin{array}{c}605,7 \\
20\end{array}$ & 99.0 \\
\hline 2. & EE Motor & $20 \mathrm{hp}$ & 60,000 & 502,600 & $\begin{array}{c}512,7 \\
00\end{array}$ & 98.0 \\
\hline 3. & $\begin{array}{l}\text { Incandescent } \\
\text { Lamp }\end{array}$ & $100 \mathrm{~W}$ & 10 & 1168 & 1198 & 97.5 \\
\hline 4. & CFL & $11 \mathrm{~W}$ & 350 & 128 & 240 & 53.6 \\
\hline
\end{tabular}

Lowering energy intensity through higher efficiency is like creating a virtual source of untapped domestic energy (Table 5.2). It may be noted that a unit of energy saved by a user is greater than a unit produced, as it saves on production losses, as well as transport, transmission and distribution losses.

Table 5.2:- Comparison of India's Energy Intensity

\begin{tabular}{|c|c|c|c|c|c|c|c|}
\hline & $\begin{array}{l}\text { TPES } \\
\text { (kgoe) }\end{array}$ & $\begin{array}{l}\text { Electricity } \\
\text { Consumption }(\mathrm{kWh})\end{array}$ & $\begin{array}{l}\text { Oil } \\
\text { (kgoe) }\end{array}$ & $\begin{array}{l}\text { Gas } \\
\text { (Cu.m.) }\end{array}$ & Coal (Kgs.) & $\begin{array}{l}\text { Nuclear } \\
(\mathbf{k W h})\end{array}$ & $\begin{array}{l}\text { Hydro } \\
\text { (kWh) }\end{array}$ \\
\hline India2004 & 304 & 585 & 110 & 29 & 257@(375) & 16 & 69 \\
\hline $\begin{array}{cr}\text { India } & 2032 \\
\text { (projected }<@ 8 \% \text { GDPgrowth) }\end{array}$ & 1112 & 2643 & 296 & 170 & 927@(1390) & 300 & 341 \\
\hline World Average (2003) & 1688 & 2429 & 635 & 538 & 740 & 403 & 423 \\
\hline OECD (2003) & 4668 & 8044 & 2099 & 1144 & 1651 & 1924 & 1076 \\
\hline U.S.A. (2003) & 7840 & 13066 & 3426 & 2176 & 3410 & 2624 & 948 \\
\hline China (2003) & 1090 & 1379 & 213 & 32 & 1073 & 32 & 215 \\
\hline South Korea (2003) & 4272 & 7007 & 2264 & 627 & 1541 & 2570 & 101 \\
\hline Japan (2003) & 4056 & 7816 & 2146 & 845 & 1247 & 1859 & 816 \\
\hline
\end{tabular}


@ $\quad$ Per capita coal consumption of India has been estimated based on the calorific value of hard coal used internationally with a calorific value of $6000 \mathrm{kcal} / \mathrm{kg}$ to maintain uniformity. The figures in brackets are actual per capita consumption based on calorific value of Indian coal i.e.,4000kcal/ka.

Source: IEA (2005), Key World Energy Statistics 2005, International Energy Agency (IEA) and Energy Information Administration, USA

Efficiency can be increased in energy extraction, energy conversion, energy transportation, as well as in energy consumption. Efficiency in energy use can make a substantial impact in mining, electricity generation, electricity transmission, electricity distribution, pumping water, industrial production processes, haulage, mass transport, building design, construction, heating ventilation \& air conditioning, lighting and household appliances. Following policies may be implemented through Memorandum of Understanding (M.O.U) among industry associations.

(a) Petroleum Conservation Research Association (PCRA) should be merged with Bureau of Energy Efficiency (BEE) under Energy Conservation Act.

(b) Increase coal use efficiency in power generation from the current average of 30.5 percent to 39 percent for all new plants.

(c) Require a least cost planning approach so that regulators permit same return on a watt saved as on the investment needed to supply an additional watt.

(d) Promote urban mass transport, freight movement by railways, and energy efficient vehicles. Enforce minimum fuel efficiency and standards for all vehicles.

(e) Reward energy efficient appliances and equipment.

(f) Enforce truthful trade marking of industrial products for energy efficiency.

(g) Promote minimum life cycle cost purchase instead of minimum initial cost procurement by government and public sector.

(h) Annual audits must include energy audits for all specified energy intensive industries and industries with a turnover exceeding say Rs. 100 crores.

(i) Establish benchmarks of energy consumption for all energy intensive sectors.

(j) Disseminate information, support training and reward best practices in energy efficiency \& energy conservation.

(k) Introducing specialization in energy efficiency/energy conservation in all engineering science disciplines.

\section{Augmenting Resources:-}

India's energy resources of India can be augmented till 2031-32 by exploration to find more of coal, oil and gas, or by recovering a higher percentage of in-place reserves [5]. Developing the thorium cycle for nuclear power and exploiting non-conventional energy, especially solar, offer possibilities for India's energy independence beyond 2050.

At a growth rate of $5 \%$ in domestic production, currently extractable coal resources will be exhausted in about 40 years. However, only about $45 \%$ of potential coal bearing area has currently been covered by regional surveys. Further, it is felt that both regional as well as detailed drilling can be made more comprehensive. Covering all coal bearing areas with comprehensive regional \& detailed drilling could make a significant difference to the estimated life of coal reserves in India. Extractable coal resources can be augmented through in-situ coal gasification to extract coal deposits and coal bed methane at greater depth.

\section{Hydro and Nuclear:-}

Even if India succeeds in exploiting its full hydro potential of 150,000 MW, the contribution of hydro to the energy demand would be around 5-6\%. Similarly, even if a 20-fold increase takes place in nuclear power capacity by 2031-32, the contribution of nuclear energy to energy demand is also expected to be $5-6 \%$, in India.

Hydro development especially storage schemes are critical for India as India's per capita water storage is the lowest among all its comparators [6]. Creating such storages is critical to India's water security, flood control and drought control. Nuclear, on the other hand, theoretically offers India the most potent means to long-term energy security. India has to succeed in realizing the development process with the help of its vast thorium resource to become truly energy independent beyond 2050.

\section{Renewables:-}

From a longer-term perspective, renewable energy sources remain important to India's energy sector. Solar energy is potentially major energy resource to attain energy independence in the long run. Even with a concerted push of 20-fold increase in capacity, renewables can account for around 5-7\% of total energy demand by 2031-32 from the present status shown in Table 8.1. While this is small, the distributed nature of renewables can provide many social benefits.

Table 8.1:- Renewable Energy Scenario

\begin{tabular}{|l|l|l|l|l|}
\hline SI.No. & Source & $\begin{array}{l}\text { Capital Cost } \\
\text { (CroresofRs/MW) }\end{array}$ & $\begin{array}{l}\text { Estimated Cost of Generation Per Unit } \\
(\text { Rs./kWh) }\end{array}$ & $\begin{array}{l}\text { Total Installed } \\
\text { Capacity (MW) }\end{array}$ \\
\hline 1 & Small Hydro-Power & $5.00-6.00$ & $2.00-3.00$ & 4379 \\
\hline 2 & Wind Power & $5.00-6.00$ & $3.00-4.00$ & 32279 \\
\hline 3 & Bio-mass Power & $4.00-5.00$ & $3.00-4.00$ & 7182 \\
\hline 4 & Bagasse Coaeneration & $4.00-5.00$ & $3.00-3.50$ & 822 \\
\hline
\end{tabular}




\begin{tabular}{|l|l|l|l|l|}
\hline 5 & Bio-mass Gasifier & $2.00-3.00$ & $3.50-4.00$ & 98 \\
\hline 6 & Solar Photovoltaic & $11.00-15.00$ & $6.00-8.00$ & 12288 \\
\hline 7 & Enerqy from Waste & $2.50-10.0$ & $2.50-7.50$ & 114 \\
\hline Source: Ministry of Non-Conventional Energy Sources(MNES) \\
\hline
\end{tabular}

Subsidy for renewables may be justified on several grounds [7]. A renewable energy source may be environmentally benign. It may be locally available making it possible to supply energy earlier than a centralized system. Grid connected renewables could improve the quality of supply and provide system benefits by generating energy at the ends of the grid where otherwise supply would have been lax. Further, renewables may provide employment and livelihood to the poor.

Power Regulators must create alternative incentive structures to encourage utilities to integrate wind, small hydro, cogeneration etc. into their systems. A subsidy could also be given in the form of a Tradable Tax Rebate Certificates (TTRC) based on energy generated. The rebate claim becomes payable depending upon the amount of electricity/energy actually certified as having been supplied.

An annual renewable energy report should be published providing details of actual performance of different renewable technologies at the state and national level. This would include actual energy supplied from different renewable options, availability, actual costs, operating and maintenance problems etc. It should also report on social benefits, employment created, women participation and empowerment. Policies for promoting many specific alternatives are suggested in the main text. These include fuel wood plantations, bio-gas plants, wood gasifier based power plants, solar thermal, solar water heaters, solar photovoltaics, bio-diesel and ethanol.

It is also recommended that Indian Renewable Energy Development Agency Ltd (IREDA) be converted into a national refinancing institution on the lines of NABARD/National Housing Bank (NHB) for the Renewable Energy Sector. IREDA's own equity base can be expanded by the financial institutions of the country instead of continuing the current system of GOI support.

\section{Energy Security:-}

Reducing energy requirement and increasing energy use efficiency are the most important measures to increase energy security [7]. The threat to energy security arises not just from the uncertainty of availability and price of imported energy, but also from the possible disruption or shortfalls in domestic production. Again, even when the country has adequate energy resources, technical failures may disrupt the supply of energy. Generators fail, transmission lines trip or oil pipeline may spring a leak. One needs to provide security against such technical risks. Risks can be reduced by reducing the requirement of energy, increasing efficiency in production and use of energy, substituting imported fuels by domestic fuels, diversifying fuel choices (gas, ethanol, bio-diesel, tar sands etc.), expanding domestic energy resource base and maintaining strategic reserves in form of large storages. In case of importing gas pipelines for importing gas do enhance security of supply if the supplying country makes a major investment in the pipeline. The most critical elements of our energy security, however, remain the measures suggested herein to increase efficiency, reduce requirements and augment the domestic energy resource base.

\section{Household Energy Security:-}

Electricity and Clean Fuels for All: One of toughest challenge is to provide electricity and clean fuels to all, particularly rural populations; considering the poor paying capacity, the limited availability of local resources for clean cooking energy and the size of the country and its population. Yet, given the fact that women and the girl child carry most of the burden of the drudgery of gathering fuel wood, agricultural wastes and animal dung and also bear the brunt of the indoor air pollution; the urgency to meet the challenge should be high, if India need to achieve universal primary education for girls, gender equality and empowerment of women. The considerable effort spent on gathering the bio-mass and the cow-dung \& preparing the same for use is having far higher price than the cost of such energy. These fuels create smoke and indoor air pollution and are inconvenient to use. They have adverse impact on the health of people, particularly women and children. Easy availability of a certain amount of clean energy, required to maintain life, should be considered as a basic necessity. Energy security at the individual level means to ensure supply of such lifeline energy in need. India cannot be energy secure if her people remain without secure supply of energy at affordable cost.

Even if one assumes that some $30 \%$ of India's households are unable to pay for a lifeline electricity consumption of 30 units /month and a loss level of about $40 \%$ in delivering these 30 units, the total need for free electricity is about $7 \%$ of the current generation. At zero cost to the consumer, this translates into a subsidy burden of about Rs.9,500 crores a year assuming the infrastructure is built under Rajiv Gandhi Grameena Vidyut Yojana (RGGVY). This burden would reduce over time as 8\% GDP growth is expected to reduce poverty at a rate that exceeds population growth. Similarly, if one assumes that the same $30 \%$ of Indian households cannot pay for a lifeline consumption of 8 cylinders of gas per annum while another $20 \%$ can only pay for $25 \%$ of the cost of supply of such lifeline consumption of gas; the subsidy burden amounts to about Rs.34,000 crores annually at Rs.450/cylinder. Again, this subsidy burden would reduce over time with economic growth and productivity of rural India apart from improvements in health and environment. 
It is pointed out that even currently over $60 \%$ of the estimated subsidy burden is being funded, although the benefits do not reach the intended beneficiaries due to poor distribution. The real issue is to direct the subsidy programme well and ensure that those falling outside the subsidy net pay the full cost of supply. A well directed subsidy regime may also be supplemented with entitlements through smart debit cards.

In addition to the subsidy other actions are also needed as follows:

(a) Finance a large scale socio-economic experiment to operate community sized bio-gas plants as a commercial enterprise either by a community cooperative or by a commercial entrepreneur, to meet the need for clean cooking energy of a sizable segment of the rural population.

(b) Even with subsidies for clean fuel, it may not be easy to reach clean fuels to the poor and they may continue to use fuel wood. As part of the above programme, improve the efficiency of domestic chullahs \& lanterns from the prevailing 10-12\% to $20-25 \%$ which is easily attainable, in conjunction with improvements of ventilation in the cooking area of the dwellings.

(c) Village woodlots within one kilometer should be developed to reduce drudgery of those who still need to gather fuel, Women's groups can form co-operatives for developing and managing fuel wood or oil seed plantations to develop sustainable energy supply, with the same efforts that they put in searching and gathering fuel wood today. Provide finance through self-help groups to transform women from fuel wood gatherers into micro-entrepreneurs in rural energy markets and energy management.

(d) Generate electricity through wood gasifiers or burning surplus bio-gas from the community bio-gas plants. Such distributed generators may be able to reach electricity to villages sooner than the grid. This will encourage such local generation, as people would not wait for the grid. Cover such distributed generation together with the local grid under the subsidy scheme of RGGVY. Formulate a tariff policy for such distributed generation for both household and productive use including agriculture.

\section{Energy Related R\&D:-}

India would find it increasingly harder to import the required commercial energy as India's share of the incremental world supply of oil \& gas could be as high as $20 \%$ since its demand is growing faster than that of industrialized nations. Research and Development (R\&D) in the energy sector is critical to augment our energy resources, to meet India's long-term energy needs, to attain energy independence, to promote energy efficiency and to enhance our energy security. R\&D requires sustained and continued support over a long period of time.

Energy related R\&D has not got the resources that it needs. India needs to substantially allocate resources for strategic energy related $R \& D$ in support with its science cities and energy entrepreneurship promotion centers. Energy related R\&D is needed to develop the concept and to prove its feasibility. This needs to be followed up by a working model at industrial parks of science cities. Scaling up to a pilot project follows with a continued interaction with potential industries, respective ministry and education research centers of universities for creating demands for energy efficient products, even if initial cost may be high. Some key policy initiatives relevant to energy related R\&D are as follows:

(a) National Energy Fund (NEF) should be set up by levying a cess of $0.1 \%$ of the turnover of all companies engaged in the field of primary/secondary energy production whose annual turnover exceeds Rs.100 crores. At 2004-05 turnover levels, this should collect Rs.500 to Rs.600 crores per year. University and schools with the help of local industries may come up with new energy efficient products. With the help of this fund as part of promoting community oriented co-operative research programmes, rather awarding individuals or individual industries.

(b) Science cities with their energy parks should develop near commercial technologies and rolling out new technologies in a time bound manner. These include coal technologies for efficiency improvement, in-situ gasification, Integrated Gas Combined Cycle (IGCC) and carbon sequestration, solar technologies for thermal and photovoltaics, bio-fuels such as bio-diesel and ethanol, bio-mass plantation, wood gasification and community based bio-gas plants.

(c) Co-operative' and federative research and development in nature friendly and open'participative entrepreneurial environment should work for more efficient industrial plant, machinery \& processes, efficient appliances, hybrid cars, super batteries, nuclear technologies related to thorium and fusion, gas hydrates, and hydrogen production, storage transport and distribution.

\section{Climate Change Concerns:-}

Concern for the threat of climate change has been an important issue in formulating the energy policy. Even though India is not required to contain its GHG emissions, as a signatory to the UN Framework Convention on Climate Change, a number of initiatives is suggested as follows: energy efficiency in all sectors, development of energy efficient public transport system, active policy on renewable energy including bio-fuels and fuel plantations, accelerated development of nuclear and hydro-electricity, technology Missions for clean coal technologies and focused R\&D on many climate friendly technologies.

\section{National Energy Modeling System:-}

National Energy Modeling System (NEMS) [8] is an economic energy modeling system which deals with production, imports, conversion, consumption, and prices of energy, macroeconomic and financial factor, world energy markets, resource availability 
and costs, behavioral and technological choice criteria, cost and performance characteristics of energy technologies, and demographics.

NEMS (Fig. 13.1) is designed to capture important fundamental interactions of macroeconomic activity, energy demand and supply in energy markets. The modules for various sub-sectors interact concurrently to design optimal solution for sustainable energy sources and environment friendly demands.

The importance of NEMS both as a concept and tool has been recognized by international planners, and such integrated analytical systems are actively being developed for arriving at cost effective and optimized supply of various energy sources for the planet.

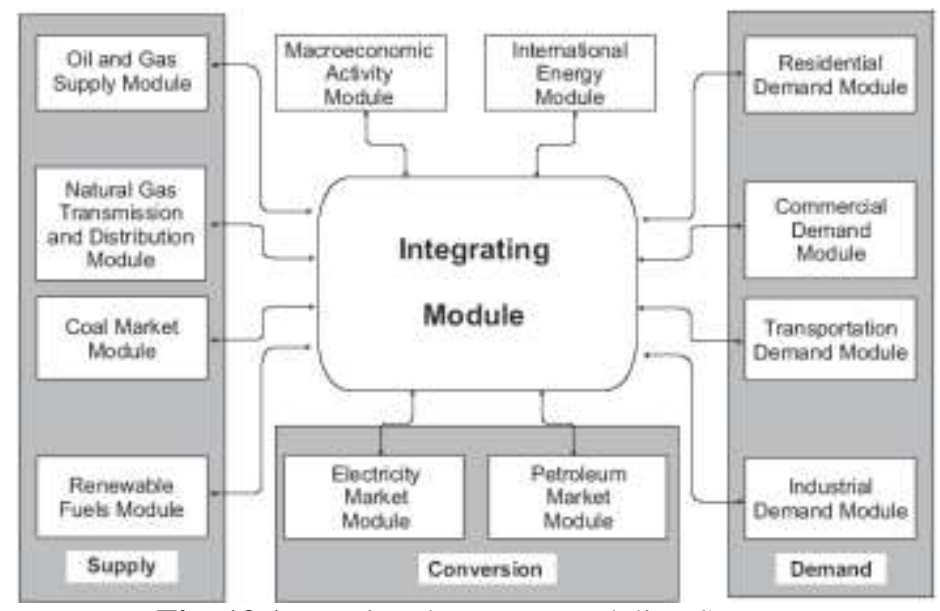

\section{Conclusion:-}

Fig. 13.1:- National Energy Modeling System

India faces an enormous challenge in meeting its energy requirement over the coming 25 years to support a growth rate of 8 percent. This challenge can be met with a coherent approach, foresight in utilizing and developing all energy resources. Recommendations are as follows:

Promoting Coal imports, accelerating power sector reforms, cutting cost of power, rationalization of fuel prices that promote efficient fuel choice and substitution, promoting energy efficiency and conservation, augmenting energy resources and supply, encouraging renewables and local solutions, enhancing energy security, promoting and focusing R\&D on energy, promoting energy security through entitlements for the poor, gender equity and empowerment, creating an enabling environment and regulatory oversight for competitive efficiency.

\section{Acknowledgements:-}

The authors gratefully acknowledge the Ministry of Non-Conventional Energy Sources, Ministry of Power, Ministry of Petroleum and Natural Gas, Ministry of Coal, and their respective PSUs for their support in data collection. The authors are also thankful to all SEBs, state PSUs and other nodal agencies for providing the required information.

\section{References:-}

1. India's Economic Development, Environmental Conservation and Energy Security, Kazuya Fujime, Managing Director, IEEJ: December 2001, 10p.

2. Reliance Review of Energy Markets, Reliance Industries Limited, (2003), 390 p.

3. Nadel S, V Kothari, S Gopinath, Opportunities for Improving End-Use Electricity Efficiency in India, American Council for an Energy-Efficient Economy, Washington, DC, (1991), 30 p.

4. Parikh J K, Reddy B S, Banerjee R, Planning for Demand Side Management in Electricity Sector, Tata Mc-Graw Hill Company Ltd., New Delhi, (1994), 187 p.

5. Parikh J K, Reddy B S, Banerjee R \& Koundinya S, DSM Survey in India: Awareness, Barrier and Implementability, Energy, 21, (10),(1996), 250p.

6. Survey Report on Water Grid of India, Central Power and Water Resources Authority of India, (1995), 397p.

7. T Stenzel, $\mathrm{T}$ Foxon, R Gross, Review of renewable energy development in Europe and the US, Report for the DTI Renewables Innovation Review, ICCEPT, Imperial College, London, October (2003), 87p.

8. Pachauri R K, Addressing the Challenge of Energy Security. A report prepared for the Asian Development Bank by The Energy and Resources Institute (TERI), New Delhi (2005), 98p.

9. National Energy Modeling System, An Overview 2003, Energy Information Administration, Department of Energy, USA, (2003), 300p. 